\title{
De nieuwbouw van Groot Batelaar in 1999: architectuur en behandelfilosofie
}

Drs. A. van den Berg*

\begin{abstract}
Algemene informatie
Groot Batelaar is een werkeenheid van de Stichting Welzijn en Gezondheidszorg van het Leger des Heils. De werkeenheid te Lunteren bestaat al geruime tijd. In 1896 werd Groot Batelaar als landloperkolonie, waar zwervers en alcoholisten werden opgevangen met behulp van werkprojecten bij boeren in de omgeving, opgericht. Na de Tweede Wereldoorlog werd in 1953 de vroegere kolonie als een open TBR -inrichting gebouwd, en kwam daarmee te vallen onder het Ministerie van Justitie. Een aantal gebouwen was tijdens de oorlog verwoest. In 1986 is de TBR -inrichting omgezet in een categoriaal psychiatrisch ziekenhuis ten behoeve van psychoneurotische delinquenten, waardoor de werkeenheid onder de verantwoordelijkheid van het huidige Ministerie van Volksgezondheid, Welzijn en Sport kwam. Deze overgang was noodzakelijk omdat de TBS -opleggingen in de loop van de jaren tachtig niet meer geschikt bleken te zijn voor een open setting. Andere juridische titels voor opname kwamen in zwang zoals de bijzondere voorwaarden bij een voorwaardelijke strafdeel, bijzondere voorwaarden bij Schorsing van de Voorlopige Hechtenis, artikel 15 lid 5 (vroeger artikel 47) van de Wet Gevangenismaatregel. Sinds 1999 is gestart met een polikliniek van Groot Batelaar in Arnhem voor jeugdigen (12-23 jaar) die met justitie in aanraking zijn gekomen, en voor nazorg van de patiënten die in de kliniek zijn opgenomen. In 2001 is tevens in Arnhem gestart met een deeltijdbehandeling voor jeugdigen.
\end{abstract}

*Drs. A. van den Berg, psycholoog/psychotherapeut en hoofd behandeling, heeft dit stuk geschreven op basis van de lezing die Drs. T.F.J.J. van Iersel, directeur, heeft gegeven voor het Lutje Psychiatrisch-Juridisch Gezelschap. 
Zo is er anno 2002 niet slechts een kliniek voor justitiabelen maar is er een circuit van hulpverleningsvormen ontstaan. Groot Batelaar heet dan ook officieel 'circuit voor forensische psychotherapie'.

Dit circuit is tevens onderdeel van een groter circuit in wording in het Arrondissement Arnhem waarin enkele forensische instellingen in de regio participeren te weten: Groot Batelaar, de Pompestichting te Nijmegen, de Forensisch Psychiatrische Afdeling van de Gelderse Roos te Wolfheze, de Forensisch Psychiatrische Dienst te Arnhem en de Reclassering te Arnhem. Met dit circuit wordt de huidige trend gevolgd dat voor patiënten op basis van de hulpvraag, hun mogelijkheden en hun stoornis een traject wordt uitgezet dat verder gaat dan een enkel instituut. In de hulpverlening dient men van elkaars behandelmogelijkheden in de regio op de hoogte te zijn en samenwerking ten behoeve van een optimaal behandeltraject voor de patiënt te zoeken.

\section{Waarom nieuwbouw?}

Sinds de kliniek Groot Batelaar begin jaren negentig haar behandelfilosofie en behandelorganisatie had veranderd werd de kliniek geconfronteerd met wachtlijsten. De 28 bedden waarvoor de kliniek erkenning had gekregen werden in 1993 uitgebreid tot 32 bedden. Er werden leefgroepen van acht patiënten samengesteld die ieder in een vaste samenstelling het gehele behandelprogramma doorliepen. Dit is in tegenstelling tot de periode voor 1993 waarin de groepen per behandelonderdeel een andere samenstelling hadden. Veel nadruk in de behandeling kwam te liggen op de volgende uitgangspunten:

1. de behandeling richt zich primair op het verminderen van de kans op delictrecidive;

2. delictgedrag is voor een groot deel terug te voeren op inadequate niet goed geleerde omgangsvormen;

3. behandeling dient zich te richten op het leren adequaat met elkaar in de groep om te gaan op basis van verschillende sociale opgaven;

4. om dit te bereiken zullen inadequate gedragspatronen omgezet worden in adequate gedragsvormen;

5. deze benadering vraagt om veel interacties in de groep waardoor in het hier en nu de gedragspatronen geanalyseerd en gecommuniceerd en met elkaar getraind kunnen worden.

Voor deze behandelvorm was de oudbouw van 1953 niet geschikt. 
De groepen liepen in hun dagelijks functioneren in ruimtelijke zin door elkaar heen, waardoor er weinig veiligheid en helderheid geboden kon worden.

De wachtlijst en de veranderde opvattingen over het behandelen van de doelgroep zorgden ervoor dat in 1993 de eerste stappen voor het realiseren van nieuwbouw werden gezet.

\section{De weg naar nieuwbouw}

De weg naar nieuwbouw was lang. Na een oriënterende fase, waarin een aantal andere klinieken werd bezocht, werd in 1994 een aanvraag verklaring bij de overheid, het ministerie van VWS, ingediend. Vele instanties dienen in het kader van zo'n aanvraag verklaring te adviseren, zoals in dit geval de Gemeente Ede, de provincie Gelderland, de inspectie voor de Geestelijke Volksgezondheid. Bij het geven van de noodzakelijke vergunningen zijn er inspraakrondes waarin diverse organisaties bezwaar kunnen indienen zoals de buurt en de milieuverenigingen. De buurt is ver gegaan in haar bezwaren — tot aan de Raad van State - maar deze werden in 1998 niet gehonoreerd. Bezwaren hadden vooral te maken met de onrust en angst die een dergelijke kliniek oproept in de buurt, hoewel de kliniek al meer dan honderd jaar op dezelfde plek stond.

Architecten werden in 1994 aangezocht om zichzelf te presenteren. Uiteindelijk werd het beroemde architectenbureau Alberts en van Huut uitgekozen om de nieuwbouw te ontwerpen. Ton Alberts is beroemd vanwege onder andere zijn ontwerpen van de Gasunie te Groningen en de NMB bank in Amsterdam Zuid-Oost. De architect was - hij is overleden vlak voor de opening van de nieuwbouw- een aanhanger van de zogenaamde organische bouw waarbij zoveel mogelijk natuurlijke materialen in de bouw worden gebruikt en rechte hoeken worden vermeden. Bij de maatgeving wordt uitgegaan van ruimtelijke verhoudingen die in de natuur voorkomen met de achterliggende gedachte dat deze architectuur rustgevende en harmonische effecten heeft. Het principe van de gulden snede wordt hierbij toegepast. In voorjaar 1998 kon de bouw starten waarna in juni 1999 de nieuwbouw betrokken kon worden.

De nieuwbouw werd gebouwd achter de bestaande gebouwen. 


\section{Uitgangspunten voor de nieuwbouw}

Voor nieuwbouw zijn er een aantal vaste gegevens zoals de financiële mogelijkheden, te weten $f 13.000 .000$ voor 51 bedden, en de maximale bebouwingsgraad van de grond die eigendom is van het Leger des Heils. Meer speelruimte is er op het gebied van de bouw zelf.

De behandeling in Groot Batelaar gaat uit van een totaalconcept zoals dat wordt gebruikt in de milieutherapie. Milieutherapie houdt in dat alle be-

standdelen die in de behandeling een rol spelen zoals het gebouw, het behandelprogramma, de samenstelling van de patiëntengroep en de behandelaars, de organisatie van de kliniek en de methodiek op elkaar dienen aan te sluiten. Een van de grote gevaren van de individuele, vraaggestuurde zorg is dat de behandeling een versnipperd karakter krijgt. Juist in de behandeling op Groot Batelaar voor jonge delinquente volwassenen met een persoonlijkheidsstoornis is een goed samenhangende behandeling van het grootste belang. Het behandelmilieu moet ontregelend werken en tegelijkertijd veiligheid bieden voor de patiënten die op een antisociale en narcistische wijze met elkaar omgaan. Het moet ontregelend zijn, omdat patiënten met persoonlijkheidsstoornissen hun eigen, vaak niet adequate, vastgeroeste gedragspatronen hebben waardoor zij op een parasiterende manier met anderen omgaan. Die inadequate gedragpatronen zijn al een onderdeel van hun persoonlijkheid geworden waartegenover de behandeling andere meer sociale gedragspatronen moet stellen. Het moet veiligheid bieden, omdat verandering van gedrag alleen goed mogelijk is als de patiënten daarmee kunnen oefenen in een accepterend en aanmoedigend behandelklimaat.

De volgende elementen in de behandeling zijn nodig om tot een positieve gedragsverandering te komen:

1. veel nadruk leggen op de dagelijkse gang van zaken zoals het wonen en werken met elkaar om zo de realiteit van alledag in de kliniek binnen te brengen;

2. de mogelijkheid scheppen van veel ontmoetingsmomenten tussen de patiënten onderling en stafleden en patiënten om interacties aan te kunnen gaan die van een gezond karakter zijn;

3. duidelijke grenzen aanbrengen tussen wat wel en niet behoort, wat wel en niet bij de patiënt hoort, wat het domein van de staf en wat het domein van de patiënten is, etc.;

4. het scheppen van een 'alsof' situatie waarin geoefend kan worden met nieuw gedrag op basis van functies, taken en rollen die de bewoners in de behandeling dienen te vervullen. Deze 'alsof' situatie vraagt om ruimte om te 'spelen'; 
5. een open sfeer creëren, in letterlijke en figuurlijke zin, waarin op basis van een drangsituatie patiënten gemotiveerd worden om hun eigen gedrag onder ogen te zien en zonodig te veranderen. De open sfeer mag in dit geval niet doorbroken worden door veiligheidsvoorzieningen zoals greppels, muren en tralies. De veiligheid en orde in de kliniek is vooral op basis van afspraken, contracten en regels gestoeld;

6. om de behandeling te laten slagen is een goede resocialisatie van belang. Dit betekent dat de behandeling veel ruimte dient te bieden voor werkvoorbereidende activiteiten zoals arbeidstherapie en studie.

Deze uitgangspunten hebben ieder hun eigen plek gekregen in de nieuwbouw.

\section{De realisering van de nieuwbouw in 1999}

De nieuwbouw is zodanig ontworpen dat voorgaande elementen op een goede manier zijn verwerkt. De organische bouw zorgt voor speelse verhoudingen zowel in de gebouwen zelf als ook aan de buitenkant ervan. De behandelunits ( 3 x 14 bedden) zijn samen met het hoofdgebouw, de opnameafdeling en het gebouw voor de vaktherapieën gelegen rondom een plein. Op het plein vinden veel veelal spontane ontmoetingen plaats. Vanuit de veelhoekige huiskamer van de units kijken de patiënten over de velden uit, wat een open sfeer uitademt. De bijpassende tuinaanleg accentueert deze open sfeer vanwege de grote grasvelden waarop prachtige beuken en kastanjes staan, die omzoomd worden door bosschages.

Elke leefgroep bestaande uit zeven patiënten heeft zijn eigen huiskamer en iedere patiënt heeft een eigen kleine kamer. In de huiskamer staat de enige televisie voor de leefgroep, waardoor de patiënten met elkaar moeten overleggen waar ze naar willen kijken. Twee leefgroepen vormen een behandelunit die samen een recreatieruimte hebben. In de recreatieruimte kunnen zij op bepaalde afgesproken tijden met elkaar recreëren. Op deze manier hebben de zeven bewoners niet slechts met elkaar te maken, maar kunnen ze hun horizon verbreden door regelmatig met andere bewoners om te gaan.

Er is ruimtelijk een onderscheid gemaakt tussen wonen in de behandelunit, werken in het activiteitencentrum en therapie in een apart gedeelte van de behandelunit. De patiënten voeren voor een groot deel hun eigen huishouding. Zij zijn verantwoordelijk voor het koken, corvee, boodschappen doen 
en het schoonmaken van hun eigen ruimtes. De keuken bevindt zich dan ook in het domein van de patiënten.

De kleuren in de verschillende units zijn pastel. De ruimtes zijn hiermee rustgevend bij de snel overprikkelde patiënten.

Op basis van deze bouw, die pas goed gaat spreken als men er geweest is, zijn namen aan de gebouwen gegeven. De namen weerspiegelen het serieuze spel van de behandeling dat met de verschillende partijen gespeeld wordt. De behandelunits heten de Lijnen, het Midden en de Grens. Het activiteitencentrum heet het Veld. De opnameafdeling heet de Basis en het hoofdgebouw met al zijn centrale voorzieningen heet het Centrum. Het plein tussen de gebouwen is tot Cirkel gedoopt.

Op deze manier heeft Groot Batelaar mede met zijn bouw een uniek samenhangend concept gerealiseerd voor de behandeling van justitiabelen. In 2002, bij het schrijven van dit stuk, lukt het steeds beter om het spel van de behandeling op een effectieve manier met elkaar te spelen. 